UDC $343.98: 343.34$

DOI: $10.31733 / 2078-3566-2019-5-17-23$

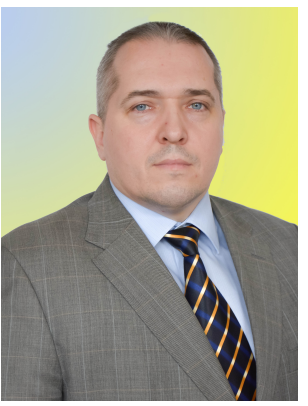

Oleh KYRYCHENKO ${ }^{\odot}$

Dr of Law, Ass. Prof.

(Dnipropetrovsk State University

of Internal Affairs)

\title{
LEGAL SUPPORT BY CRIMINAL POLICE FOR OPERATIONAL-SEARCH COMBATING CRIMES AGAINST PUBLIC SAFETY
}

ОЛЕГ КИРИчеНКО. ПРАВОВЕ ЗАБЕЗПЕЧЕННЯ КРИМІНАЛЬНОЮ ПОЛІЦЕЮ ОПЕРАТИВНО-РОЗШУКОВОЇ ПРОТИДІЇ ЗЛОЧИНАМ ПРОТИ ГРОМАДСЬКОЇ БЕЗПЕКИ. Досліджено системе правового забезпечення оперативно-розшукової протидії злочинам проти громадської безпеки кримінальною поліцією та надана класифікація нормативноправових актів, які регламентують діяльність кримінальної поліції щодо протидії цим злочинам. 3 метою удосконалення правового забезпечення оперативно-розшукової протидії злочинам проти громадської безпеки кримінальною поліцією запропоновано розробити та прийняти: 1) Закон України «Про засади протидії злочинності»; внести зміни до Закону України «Про оперативнорозшукову діяльність» відповідно до вимог норм КПК України та потреб правоохоронної діяльності; 2) Концепцію реалізації державної політики у сфері профілактики правопорушень на період до 2025 р. і Концепцію протидії злочинам проти громадської безпеки; 3) комплексну програму протидії злочинам терористичної спрямованості; злочинам, що пов'язані зі створенням банд, злочинних організацій та незаконних воєнізованих або збройних формувань; злочинам, що пов'язані з незаконними обігом вогнепальної зброї, бойових припасів і вибухових речовин; 4) нормативно-правовий акт Національної поліції, який би регламентував діяльність кримінальної поліції та окремих оперативних підрозділів кримінальної поліції щодо профілактики злочинів.

Ключові слова: злочини проти громадської безпеки, кримінальна полічія, оперативнорозшукова протидія, нормативно-правовий акт, стратегія.

Problem statement. During the reform of the law-enforcement bodies system of Ukraine, they are faced with new tasks to identify strategic directions of their activity, to find new approaches to combat organized crime, which would correspond to the realities of today and take into account the trends of development of society and the country. Particularly relevant is the need to research scientific ideas and approaches to make a qualitatively new mechanism for combatting crimes against public safety, identify and analyze its components, improve relevant current legislation and enforcement practices.

The effective functioning and operation of law enforcement agencies depends first and foremost on their legal regulation. However, the analysis of regulations shows that there is no common view and understanding of the threats posed by crime, and their strategic planning of approaches and assessments of problems, their solutions are fragmentary and inconsistent. At the same time, the demands of developing and implementing a clear, transparent and consistent criminal policy that take into account changes in the transitional penal and law enforcement model to the law enforcement and social service content of their activities are increasingly being raised in society. Some civil society institutes and some scholars have initiated documents that can form the basis of the state's criminal policy. In view of this, the scientific interest in contemporary problems related to criminal police activities in combating crimes against public safety, their relationship with other law enforcement agencies, public authorities and civil society institutions tends to increase.

Analysis of publications that started solving this problem. Significant contribution to the development of theoretical and legal problems of operational-search combating certain types of crimes against public safety was made by complex monograph works by S.V. Didenko, V.M. Yevdokimov, B.V. Zhukov, V.V. Krutov, Y.S. Lenyuk, P.M. Mitrukhov, V.P. Mezhivoy, R.V. Mukoida, D.Yo. Nikiforchuk, S.V. Pecherytsya, O.O. Podobnyy and oth-

\footnotetext{
(C) Kyrychenko O., 2019

ORCID iD: https://orcid.org/0000- 0002-2046-9522

kirichenkooleg75@ukr.net
} 
ers. However, despite the wide range of substantive scientific works on the mentioned issues, it should be noted that the problem of legal support of the operational-search combating crimes against public safety by the criminal police has not found its proper treatment.

The article's objective is to study the system of legal support for operational-search combating crimes against public safety by criminal police; to classify the regulations concerning the activity of criminal police in combating crimes against public safety, and to determine the directions for improving the legal support of operational-search combating these crimes.

Basic content. It is well known that the legal bases of operational search activity are legal rules that directly regulate its organizational and tactical bases or define certain conditions under which it becomes possible and necessary to use undercover forces, means and methods of this activity. Legal rules also regulate legal relations arising between operational units of various law enforcement agencies of Ukraine, between operational units and citizens, officials, organizations, institutions, enterprises, etc., who are in the field of operational search activities or are involved in the fulfilment of its tasks. The legal foundations of operational-search activity also include the fact that the rules governing legal relations, by their epistemological essence, are established in order to protect the rule of law, human rights and freedoms, are carried out in the interests of criminal justice, and in their totality form the operational-search legislation $[1$, p. 13-14].

Therefore, the legal basis for regulating operational-search combating crimes against public safety is a set of interrelated legal acts aimed at combating these crimes.

The multiplicity of these acts implies the need for their classification. In the vocabulary literature, the classification of legal scholars traditionally refers to the system of subcontracted concepts (classes, objects) of a particular field of knowledge or human activity, which are used as a means of establishing links between these concepts or classes of objects [2, p. 357]. In our opinion, the classification of legal acts regulating the operational-search combating crimes against public safety is a complex theoretical and methodological process, the content of which is to identify the criteria of this classification and their division into separate groups in order to further systematize them.

Due to the fact that there is no consensus among scientists regarding the choice of criteria for classification of normative legal acts regulating the operati operational-search combating crimes against public safety, which are their basis, we consider that the criterion of such classification is appropriate to determine the internal content of these acts, that is, we propose to divide the said acts by legal force into the following groups: 1) acts regulating in general the activities of the subjects of operational-search combating crimes against public safety (bodies of Nnational police, the Security Service, etc.); 2) acts defining the competence, goals, tasks and directions of activity of criminal police units as the main subject of operational-search combating crimes against public safety; 3 ) acts of a general nature that ensure the functioning of the social and legal mechanism for combating crime; 4) acts regulating the operationalsearch activity and regulating organizational and tactical issues of the use of forces, means and methods of this activity; 5) acts aimed at combating certain types of crime, the structure of which includes a certain group of crimes against public safety, and certain types of crimes against public safety [3, p. 66-67].

Given that the purpose of any classification is to ascertain the substantive nature, we propose to consider the normative-legal acts that regulate the operational-search combating crimes against public safety, proceeding from the division of these acts by legal force, which in turn should be conditional classified into general and special.

We refer to the general normative legal acts as those which are aimed generally at combating crime, including the fight against crimes against public security, and to the special ones - the acts directly aimed at combating crimes against public safety.

In our view, such criteria should be categorized into: general and special purpose legislation; by-laws of general and special purpose.

General legislative acts should include: 1) international legal acts, the consent of which has been given by the Verkhovna Rada of Ukraine (Universal Declaration of Human Rights; International Covenant on Civil and Political Rights; International Covenant on Economic, Social and Cultural Rights; Convention) on the protection of human rights and fundamental freedoms; Guidelines on crime prevention and criminal justice; Resolution of the 9th United Nations Congress on Crime Prevention and Treatment of Offenders); 2) codified acts that ensure the functioning of the social and legal mechanism for combating crime (Criminal, Criminal Procedural and Criminal Executive Codes of Ukraine); 3) laws of Ukraine that comprehen- 
sively regulate the status, tasks, functions, powers, rights and duties of law enforcement agencies, including the National Police bodies, as well as acts aimed at combating crimes in general or certain criminal acts ("On the National police" of 02.07.2015; "On the Security Service of Ukraine"of 25.03.1992; "On the Prosecutor's Office" of 14.10.2014; "On the operational-search activities" of 18.02.1992;" On organizational and legal bases of combating organized crime" of 30.06.1993; "On Prevention of Corruption" of 14.10.2014; "On Measures to Combat Illicit Trafficking in Drugs, Psychotropic Substances and Precursors" of 15.02.1995).

Specific legislative acts should include: 1) international legal acts, the consent of which has been given by the Verkhovna Rada of Ukraine (European Convention for the Suppression of Terrorism, ratified by the Law of Ukraine of 29.01.2002 No. 2990-III; International Convention for the Suppression of Terrorism) with the bombing of terrorism ratified by the Law of Ukraine of 28.11.2001 No. 2855-III; the International Convention for the Suppression of the Financing of Terrorism ratified by the Law of Ukraine of September 12, 2002 No. 149-IV; Protocol against the Illicit Manufacturing and Use of Firearms, components and parts, as well as ammunition thereto, supplementing the United Nations Convention against Transnational Organized Crime, approved by General Assembly Resolution 55/255 of 31.05.2001 and ratified by Law of Ukraine No 159VII of 02.04.2013; 2) the laws of Ukraine ("On Combating Terrorism" of 20.03.2003; "On Preventing and Countering the Legalization (Laundering) of Proceeds of Crime or Terrorist Financing" of 28.11.2002; "On the Physical Protection of Nuclear Installations, Nuclear Materials, radioactive waste, other sources of ionizing radiation "of 19.10.2000).

The general by-laws include: 1) decrees of the President of Ukraine ("On measures to further strengthen law and order, protection of citizens' rights and freedoms" of 18.02.2002 No. 143/2002; "On measures to ensure the personal safety of citizens and combating crime" of 10.07.2005 No. 1119/2005; "On the Concept of State Policy in the Field of Organized Crime" of 21.10.2011 No. 1000/2011; "On the Decision of the National Security and Defense Council of Ukraine of 06.05.2015 "On the National Security Strategy of Ukraine" of May 26, 2015, No. 287/2015; "On the decision of the National Security and Defense Council of Ukraine of 06.16.2015 "On measures to strengthen combating crime in Ukraine" of 16.06.2015 No.341/2015); 2) Order of the Cabinet of Ministers of Ukraine "On Approval of the Plan of Measures for Implementation of the Concept of State Policy in the Field of Organized Crime" of 25.01.2012 No. 53-p; 3) joint orders of law enforcement agencies regulating the organization of undercover investigative (search) actions and the use of their results in criminal proceedings; conducting certain types of operational-search measures and undrcover investigative (search) actions; 4) orders of the Ministry of Internal Affairs of Ukraine, including the National Police, which regulate the activity of the operational units of the National Police, the organization of operational-search activities and the covered work of such units.

The special-purpose by-laws should include: 1) decrees of the President of Ukraine ("On the Concept of Anti-Terrorism" of 05.03.2019 No. 53/2019; "On the decision of the National Security and Defense Council of April 13, 2014 "On urgent measures to overcome the terrorist threat and the preservation of the territorial integrity of Ukraine" of 14.04.2014 No. 405/2014); 2) Resolution of the Cabinet of Ministers of Ukraine ("On Approving the Procedure of Interaction of Executive Bodies and Legal Entities Performing Activities in the Field of Nuclear Energy Use in the Case of Detection of Illegal Ionizing Radiation in Illicit Circulation" of 02.06.2003 No. 813; 3) orders of the MIA of Ukraine, which regulates the circulation of firearms, air and cold weapons, as well as specific directions for the search for such items that are illegally owned.

We believe that the proposed classification of legal acts will provide researchers with the opportunity to further systematize it and identify weaknesses in the legal regulation of operational-search combating crimes against public safety.

Improving the effectiveness of the activities of the National Police bodies and units, the state of protection of citizens' rights and freedoms, public safety are completely dependent on the level of legislative support. But, unfortunately, today there is no normative legal act in Ukraine that would regulate public relations on combating crime. That is why it is necessary to agree with some scholars' opinion, that "one of the reasons for the poor quality of many laws is the lag of the legal science in theoretical elaboration and the solution of the issues requiring legislative regulation. Instead of going ahead of the legislator, legal science either substantiates or criticizes already adopted laws" [4, p. 296].

Despite the fact that a number of laws are in force in the country to prevent the commitment of certain types of crimes, in our opinion, it is also necessary to adopt the Law of 
Ukraine "On Principles of Combating Crime", which should provide a definition of the category "combatingo crime", including "operational-search combating crimes" as a kind of counteraction to crimes, its forms, forces and means, etc. [5, p. 146]. Adoption of the mentioned legal act will only contribute to the development of a strategy for combating crime in general and certain types of crime, including crimes against public safety.

It should be emphasized that the strategy for combating crime against public safety should be based on the strategy for combating crime in society. About this V.M. Kudryavtsev noted that the strategy for combating crime in modern society is complicated and uncertain, mainly because two trends are simultaneously operating in this area, which are largely contrary to each other. On the one hand, a society that wants to live by democratic laws must humanize its criminal policy. Safeguarding and protection of human rights affect not only free citizens, but also offenders within the law. On the other hand, crime around the world is taking on such dangerous forms that the law enforcement system does not cope with by traditional means. The population is demoralized by rising crime and dissatisfied with the powerlessness of the authorities. The society demands more punishment and extraordinary measures for combating crime [6, p. 213-214].

The combating crime strategy is based on the principle of a gradual solution to this global problem. Taking into account the criminogenic situation in the country, the priority tasks and directions of combating crime, its specific types, are determined for a certain period of time.

The Strategy for Combating Crimes against Public Safety contributes to solving the problems of operational-search combating these crimes. Some aspects of the strategy are reflected in regulations aimed at ensuring the national security of the state, counteracting terrorist activity and organized crime, as well as crimes that violate the rules of treatment of certain sources of general (increased) danger. For example, according to the NSDC Decision "On Measures to Enhance Crime Fighting in Ukraine" of May 6, 2015, enacted by Presidential Decree No. 341/2015 of June 16, 2015, and to prevent exacerbation of the crime situation in certain regions of Ukraine, minimizing the impact of relevant threatening factors on national security, enhancing the effectiveness of the protection of citizens' rights and freedoms was identified as a priority area in combating crimes against public safety, in particular: 1) reducing the crime rate in the country illicit trafficking of firearms and other weapons, ammunition, explosives; 2) detection and elimination of smuggling channels, illegal movement of firearms, other means of destruction, explosives through the territory of Ukraine; 3) strengthening of control on objects where firearms are concentrated, other means of destruction, ammunition, explosives; 4) suppression of acts of banditry, ensuring of high-quality pre-trial investigation and bringing to court the existing criminal proceedings in cases of banditry, crimes committed by organized groups or criminal organizations; 5) detection and termination of financing channels for gangs and smuggling of firearms and other means of destruction, ammunition, explosives [7].

The strategy of combating crime is defined by the concept, which is a system of officially adopted views and ideas, principles and provisions on ways, means and mechanisms of protection of vital interests of citizens, society and the state from internal and external threats arising from crime [10, p. 414].

Until recently, the main normative legal act aimed at combating crime was the Concept of implementation of state policy in the field of crime prevention for the period up to 2015, approved by the decree of the Cabinet of Ministers of Ukraine of November 30, 2011 No. 1209, which expired on December 31, 2015. But based on the analysis of statistics and taking into account the criminogenic situation in the country and current trends in the existence and spread of crime, we believe that in Ukraine it is necessary to adopt a similar Concept for the period up to 2025 , which should address the issue of combating certain types of crime, including crimes against public safety.

It should be noted that the concept of combating crimes against public safety is a set of basic theoretical propositions that reveal the content of the factors, the state and prediction of the spread of terrorist offenses, crimes related to the creation of gangs, criminal organizations and illegal militarized or armed groups, crimes that violate the rules for the management of individual sources of general (increased) danger in the country (or in a particular region), basic concepts, objectives, principles and main directions to respond these crimes. This concept should, in our opinion, cover the following areas: 1) description of crimes against public safety and the main trends of their spread; 2) determinants of crimes against public safety; 3) strategy for combating public safety crimes; 4) forces and means of combating public safety crimes; 
5) system of nationwide measures to combat public safety crimes; 6) the main directions of combating crimes against public safety by law enforcement agencies; 7) coordination and interaction in the field of combating crimes against public safety; 8) organization of international cooperation in the field of combating crimes against public safety.

The main purpose of combating crimes against public safety is to comprehensively ensure public safety and reliable protection of human rights and freedoms, property from criminal offenses, which are attributed by the current Criminal Code of Ukraine to crimes against public safety. That is why the main efforts of state bodies and society should be directed to the real restriction and cessation of all forms and types of criminal activity that violate public safety as a value. At the same time, it will be strategically important to take a number of legal measures to provide real actors with crime-fighting tools that will allow them to continue to effectively combat public safety crimes.

In view of the above, we consider it necessary to develop comprehensive programs at national or regional level to combat terrorist offenses; crimes related to the creation of gangs, criminal organizations and illegal militarized or armed groups; crimes related to the trafficking of firearms, ammunition and explosives. For example, R.V. Mukoida proposes to create a centralized national program for combating terrorist offenses, which should include the implementation of a variety of measures available: intelligence, deterrence, prevention, investigation, preventive action [8, p. 17].

The Criminal Procedural Code of Ukraine is of particular importance in combating crime in general, including organized crime, and crimes against public safety. Although this legislative act identified the preventive focus of search and operational activity as the main one, it did not give the operational units the necessary powers to effectively prevent crime.

Regarding the adoption of the Criminal Procedural Code of Ukraine, amendments were made to the current version of the Law of Ukraine "On Operational-Search Activities" [9], which, in our view, only exacerbated the contradictions between the provisions of these legislative acts, in particular, in the rules, which reads on the place and role of law enforcement units in combating criminal offenses, the uncertainty of the range of operational search measures, etc. Therefore, in order to improve the current law-enforcement legislation, we also propose to make the following proposals: to implement the common terminology in the Criminal Procedural Code of Ukraine and in the Law of Ukraine "On Operational-Search Activity"; to consolidate in the Law of Ukraine "On Operational-Search Activities" the definition of the term "Operational-Search Measure", as well as to provide an exhaustive list of operational search measures in accordance with the Criminal Procedural Code of Ukraine and to disclose their essence. Thus types of operational-search measures should be identical to types of undercover investigative (search) actions.

The analysis of the normative legal acts of Ukraine gives us grounds to assert that the legal regulation of the operational-search combating crimes against public safety by the criminal police is imperfect. Therefore, legal acts need improvement in the light of current changes in theoretical approaches to determining the combating crime, reforming the criminal procedural and operational-search legislation of Ukraine, modernization of the law enforcement system of the country. In our view, in addition to the current provisions on criminal police units, a common regulatory act is the Criminal Police Regulations, which will help to coordinate the performance and functions of criminal police units, ensure effective interaction of these units, needs to be developed and adopted. It should be noted that during the development of these acts it is necessary to: eliminate the contradictions between the formulation of the provisions of these acts - that is, the prescriptions relating to certain aspects of activity should not be reflected in other regulations of this area; they should contain the principles, tasks, functions and forms of specialization of criminal police units, the main provisions of the organization of their activities.

Taking into account the preventive function of criminal police units, it should be noted that today there is a problem of imperfect legal regulation of crime prevention by operational units of the National Police, as well as the lack of a separate departmental regulatory legal act, which in turn makes artificial obstacles in the implementation of this activity. In our view, there is an urgent need to issue a departmental regulatory act that would regulate the activities of National Police bodies and units in crime prevention by operational units.

Conclusions. On the basis of the analysis of the current normative-legal acts regulating the operational-search activity and criminal police activity, in particular with regard to combating crimes against public safety, we propose to expand the content and scope of improvement of the 
legal basis of this type of activity by criminal police. To this end, it is necessary to develop and adopt: 1) the Law of Ukraine "On Principles of Combating Crime"; to amend the Law of Ukraine "On Operational-Search Activities" in accordance with the requirements of the Criminal Procedural Code of Ukraine and the needs of law enforcement activities; 2) Concept of implementation of state policy in the field of prevention offenses for the period up to 2025 and Concept of combating crimes against public safety; 3) a comprehensive program for combating terrorist offenses; crimes related to the creation of gangs, criminal organizations and illegal militarized or armed groups; crimes related to illicit trafficking in firearms, ammunition and explosives; 4) a normative-legal act of the National Police, which would regulate the activities of the criminal police and individual operational units of the criminal police in crime prevention.

\section{References:}

1. Регульський В. Л. Оперативно-розшукова діяльність органів внутрішніх справ: правові та організаційні основи: автореф. дис. ... канд. юрид. наук: 21.07 .04 / Нац. акад. внутр. справ. Київ, 1997. 27 c.

2. Великий енциклопедичний юридичний словник / за ред. Ю. С. Шемшученка. Київ: ТОВ Вид-во «Юридична думка», 2007. 992 с.

3. Кириченко О. В. Класифікація нормативно-правових актів, що регламентують оперативно-розшукову протидію злочинам проти громадської безпеки. Актуальні питання оперативно-розшукової протидії злочинам: матеріали наук.-практ. семінару (Дніпропетровськ, 16 травня 2014 р.). Дніпропетровськ : Дніпроп. держ. ун-т внутр. справ 2014. С. 66-69.

4. Баляба А. В., Виленская Э. В., Дидоренко Э. А., Розовский Б. Г. Криминология: приглашение к дискуссии: монограф. Луганск: РИО ЛИВД, 2000. 318 с.

5. Кириченко О. В. Предотвращение преступлений в системе противодействия преступности. Актуальные проблемы теории и истории права и государства на современном этапе: сб. науч. тр. IX Междунар. науч.-практ. конф. ; отв. ред. А. С. Евстегнеев. Кострома : Костром. гос. технол. ун-т, 2012. С. 144-147. 2002. 238 c

6. Кудрявцев В.Н. Преступность и нравы переходного общества: монограф. М. : Гардарики,

7. Про рішення Ради національної безпеки і оборони України від 06.05.2015 р. «Про заходи щодо посилення боротьби зі злочинністю в Україні»: Указ Президента України від 16.06.2015 № 341/2015. URL: http://www.president.gov.ua/documents/3412015-19136.

8. Мукоіда Р. В. Організаційно-тактичні засади протидії злочинам, пов'язаним 3 терористичною діяльністю: автореф. дис. ... канд. юрид. наук: 21.07 .04 / Одес. юрид. ін.-т ХНУВС. Одеса, 2008. $21 \mathrm{c.}$

9. Про внесення змін до деяких законодавчих актів України у зв'язку 3 прийняттям Кримінального процесуального кодексу України: Закон України від 13.04.2012. URL : http://zakon.rada.gov.ua.

Received to editorial office 06.12.2019

1. Rehul's'kyy, V. L. (1997) Operatyvno-rozshukova diyal'nist' orhaniv vnutrishnikh sprav: pravovi ta orhanizatsiyni osnovy [Operational search activities of law enforcement agencies: legal and organizational bases]: avtoref. dys. ... kand. yuryd. nauk: 21.07.04 / Nats. akad. vnutr. sprav. Kyiv, 27 s. [in Ukr.]

2. Velykyy entsyklopedychnyy yurydychnyy slovnyk [Big Encyclopedic Legal Dictionary] / za red. YU. S. Shemshuchenka. Kyiv: TOV Vyd-vo «Yurydychna dumka», 2007. 992 s. [in Ukr.]

3. Kyrychenko, O. V. (2014) Klasyfikatsiya normatyvno-pravovykh aktiv, shcho rehlamentuyut' operatyvno-rozshukovu protydiyu zlochynam proty hromads'koyi bezpeky [Classification of normativelegal acts regulating operational-search combating crimes against public safety]. Aktual'ni pytannya operatyvno-rozshukovoyi protydiyi zlochynam: materialy nauk.-prakt. seminaru (Dnipropetrovs'k, 16 travnya 2014 r.). Dnipropetrovs'k : Dniprop. derzh. un-t vnutr. sprav. S. 66-69. [in Ukr.]

4. Balyaba, A. V., Vilenskaya, É. V., Didorenko, É. A., Rozovskiy B. G. (2000) Kriminologiya: pryglasheniye $\mathrm{k}$ diskussii [Criminology: invitation to discussion]: monograf. Lugansk: RIO LIVD,. $318 \mathrm{~s}$. [in Russ.]

5. Kyrychenko, O. V. (2012) Predotvrashcheniye prestupleniy v sisteme protivodeystviya prestupnosti [Crime prevention in the system of combating crime]. Aktual'nye problemy teorii $i$ istorii prava i gosudarstva na sovremennom étape: sb. nauch. tr. IX Mezhdunar. nauch.-prakt. konf. ; otv. red. A. S. Yevstegneyev. Kostroma : Kostrom. gos. tekhnol. un-t. S. 144-147. [in Russ.]

6. Kudryavtsev, V.N. (2002) Prestupnost' i nravy perekhodnogo obshchestva [Crime and the morals of a transitional society]: monograf. M. : Gardariki, 238 s. [in Russ.]

7. Pro rishennya Rady natsional'noyi bezpeky i oborony Ukrayiny vid 06.05.2015 r. «Pro zakhody shchodo posylennya borot'by zi zlochynnistyu v Ukrayini» [On the decision of the National Security and Defense Council of Ukraine of May 6, 2015 "On measures to strengthen the fight against crime in Ukraine”] : Ukaz Prezydenta Ukrayiny vid 16.06.2015 № 341/2015. URL : 
http://www.president.gov.ua/documents/3412015-19136. [in Ukr.]

8. Mukoida, R. V. (2008) Orhanizatsiyno-taktychni zasady protydiyi zlochynam, pov"yazanym z terorystychnoyu diyal'nistyu [Organizational and tactical principles of combating crimes related to terrorist activity]: avtoref. dys. ... kand. yuryd. nauk: 21.07.04 / Odes. yuryd. in.-t KHNUVS. Odesa, 21 s. [in Ukr.]

9. Pro vnesennya zmin do deyakykh zakonodavchykh aktiv Ukrayiny u zv"yazku z pryynyattyam Kryminal'noho protsesual'noho kodeksu Ukrayiny [On amendments to some legislative acts of Ukraine in connection with the adoption of the Criminal Procedural Code of Ukraine] : Zakon Ukrayiny vid 13.04.2012. URL : http://zakon.rada.gov.ua. [in Ukr.]

\title{
Summary
}

The article deals with the system of legal support for operational and investigative counteraction to crimes against public safety by criminal police. The author has classifyied the normative-legal acts regulating the activity of criminal police in combating crimes against public security, and has determined the directions for improving the legal support of operative-investigative counteraction to these crimes. $\mathrm{He}$ has proposed to expand the content and scope of improvement of the legal basis of this type of activity by criminal police.

Ключові слова: злочини проти громадської безпеки, кримінальна полічія, оперативнорозшукова протидія, законодавчо-правовий акт, стратегія

UDC УДК 340.116:355.4

DOI: $10.31733 / 2078-3566-2019-5-23-29$

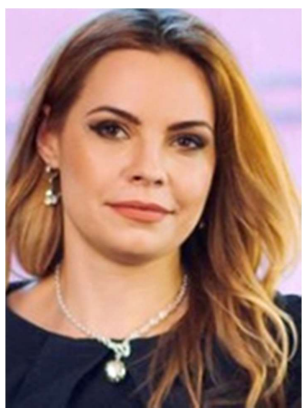

Yuliana

NAYDYON ${ }^{\circledR}$

Dr of Law, Ass. Prof.

(National Academy

of Security Service

of Ukraine)

\author{
Oleksandr \\ SHAMARA ${ }^{\mathbb{C}}$ \\ Ph.D, Snr Researcher \\ (National Academy \\ of Public Prosecutor \\ of Ukraine)
}

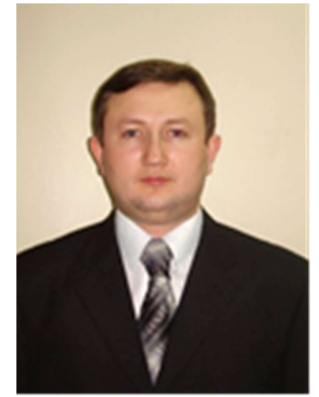

\section{CONTENTS AND NATURE OF OPERATIONAL ACTIVITIES OF THE STATE BODY OF SPECIAL PURPOSE WITH LAW ENFORCEMENT FUNCTIONS}

\begin{abstract}
Юліана Найдьон, Олександр Шамара. ЗМІСТ ТА СУТНІСТЬ ОПЕРАТИВНОї ДІЯЛЬНОСТІ ДЕРЖАВНОГО ОРГАНУ СПЕЦІАЛЬНОГО ПРИЗНАЧЕННЯ 3 ПРАВОХОРОННИМИ ФУНКЦІЯМИ. Однією із нагальних проблем наукового забезпечення оперативної діяльності державного органу спеціального призначення 3 правоохоронними функціями $є$ створення іiі єдиної теорії, основоположними засадами якої $\epsilon$ теоретико-правове розуміння останньої, визначення іiі сутності та змісту, формування методологічних підходів до іiї
\end{abstract} побудови.

Стаття присвячена розгляду поняття оперативної діяльності державного органу спеціального призначення з правоохоронними функціями як основоположної категорії відповідної теорії та практики. Вивчення та узагальнення практики існування досліджуваного явища стало методологічною основою виведення поняття оперативної діяльності. Виведено істотні ознаки, притаманні оперативній діяльності державного органу спеціального призначення 3 правоохоронними функціями, що лягло в основу вироблення відповідного поняття.

Зроблено висновок, що науковці різних історичних періодів серед інших видів діяльності, що мають здійснювати органи державної безпеки для виконання покладених на них завдань, виокремлюють певний вид негласної діяльності - оперативної, що здійснюється із застосуванням

\footnotetext{
(C) Naydyon Yu., 2019

academy@ssu.gov.ua

ORCID iD: https://orcid.org/0000-0002-1076-0471

(C) Shamara O., 2019

ORCID iD: https://orcid.org/0000-0002-0571-0437

napu@ap.gp.gov.ua
} 